DOI: https://doi.org/10.24127/ajpm.v9i4.2976

\title{
BAHAN AJAR MATEMATIKA BERBASIS KONTEKSTUAL PADA MATERI FUNGSI UNTUK MENINGKATKAN KEMAMPUAN PEMECAHAN MASALAH MATEMATIS
}

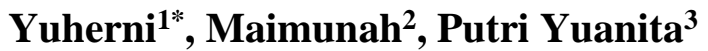 \\ $1^{*}, 2,3$ Universitas Riau, Pekanbaru, Indonesia \\ *Corresponding author. \\ E-mail: $\quad$ yuherni_02@yahoo.co.id ${ }^{1 *}$ \\ maimunah@lecturer.unri.ac.id ${ }^{2)}$ \\ put_yuanita@yahoo.co.id ${ }^{3)}$
}

Received 21 July 2020; Received in revised form 21 December 2020; Accepted 31 December 2020

\begin{abstract}
Abstrak
Tujuan penelitian ini adalah menghasilkan bahan ajar berbasis kontekstual pada materi fungsi untuk meningkatkan kemampuan pemecahan masalah matematis peserta didik kelas X SMA Negeri 1 Rambah. Jenis penelitian adalah penelitian pengembangan (Research \& Development) menggunakan model pengembangan Bord and Gall Instrumen penelitian berupa lembar validasi, lembar angket respon peserta didik dan tes kemampuan pemecahan masalah matematis (KPMM).Persentase rata-rata hasil validasi bahan ajar panduan peserta didik adalah 81,09\% dengan kategori sangat valid dan persentase bahan ajar panduan guru adalah $87,01 \%$ dengan kategori sangat valid. Hasil angket repon peserta didik terhadap bahan ajar sebesar 84,05\% dengan kategori sangat praktis dan tidak ada revisi lagi sehingga bahan ajar praktis digunakan dalam pembelajaran matematika materi fungsi. Hasil uji coba bahan ajar berdasarkan tes KPMM peserta didik menunjukkan bahwa nilai rata-rata KPMM peserta didik kelas eksperimen $(89,16)$ lebih tinggi dari pada kelas kontrol $(67,97)$. Berdasarkan tingkat kevalidan, kepraktisan dan keefektifan maka pengembangan bahan ajar matematika berbasis kontekstual dapat meningkatkan KPMM peserta didik pada materi fungsi.
\end{abstract}

Kata kunci: bahan ajar; kontekstual; pemecahan masalah matematis

\begin{abstract}
The purpose of this study is to produce contextual-based teaching materials on function materials to improve the mathematical problem solving capabilities of students in Grade X of Sma Negeri 1 Rambah. This type of research isresearch \& development using Bord and Gall development model. Research instruments in the form of validation sheets, questionnaires of students' responses and tests of mathematical problem solving skills (KPMM). The percentageof rata-average teacher guide teaching material validation results is $81.09 \%$ with a very valid category and the percentage of teacher guide teaching materials is $87.01 \%$ with a very valid category. The results of the student repon questionnaire on teaching materials amounted to $84.05 \%$ with very practical categories and no revisions so that practical teaching materials were used in the learning of mathematical function materials. The results of the teaching materials trial based on the KPMM test of the learners showed that the average score of the experiment class students (89.16) was higher than in the control class (67.97). Based on the level of validity, practicality and effectiveness, the development of contextual-based mathematical teachingmaterials can increase the KPMM of students in fungsi materials.
\end{abstract}

Keywords: teaching materials; contextual; mathematical troubleshooting

This is an open access article under the Creative Commons Attribution 4.0 International License 
DOI: https://doi.org/10.24127/ajpm.v9i4.2976

\section{PENDAHULUAN}

$\begin{array}{llr}\text { Kurikulum merupakan } & \text { acuan } \\ \text { dalam penyelenggaraan } & \text { sistem } \\ \text { pendidikan. } \quad \text { Kurikulum } & \text { berisi }\end{array}$ seperangkat rencana dan pengaturan mengenai tujuan, isi, dan bahan ajar atau sumber belajar yang digunakan sebagai pedoman dalam kegiatan pembelajaran untuk mencapai tujuan pendidikan tertentu.

$$
\text { Pembelajaran yang efektif }
$$
terjadi jika peserta didik dapat mengembangkan cara berfikirnya dan mampu mengaitkan pengetahuan yang dimilikinya dengan kehidupan nyata peserta didik (Kurniati, 2018). Seorang guru harus memiliki tehnik penyajian pelajaran dengan menyediakan bahan ajar yang dapat ditangkap, dikuasai, dipahami, dan digunakan oleh peserta didik dengan efektif (Astiti \& Yusuf, 2018). Bahan ajar sangat penting baik bagi guru maupun bagi peserta didik dalam proses belajar mengajar. Jika dalam pembelajaran tidak menggunakan bahan ajar, maka guru akan mengalami kesulitan dalam meningkatkan efektivitas pembelajaran dan peserta didik akan sulit memahami materi yang diajarkan (Perwitasari, Wahjoedi, \& Akbar, 2018).

Bahan ajar yang sesuai dengan lingkungan peserta didik dapat menimbulkan suasana pembelajaran lebih bermakna (Purwanto \& Rizki, 2015). Bahan ajar yang sesuai dengan lingkungan peserta didik adalah bahan ajar berbasis kontekstual. Peserta didik dapat terbantu dalam membangun konsep yang dimilikinya melalui materi pada bahan ajar berbasis kontekstual yang memuat kejadian-kejadian nyata dalam kehidupan peserta didik seharihari (Ibrahim, 2012). Ketersediaan bahan ajar di sekolah tingkat menengah atas saat ini adalah bahan ajar dari pemerintah atau penerbit yang belum berbasis kontekstual (Kurniati, 2018). Menurut Kurniati (2018) ketersediaan bahan ajar di sekolah tingkat menengah atas saat ini adalah bahan ajar dari pemerintah atau penerbit yang belum berbasis kontekstual dan belum menyajikan penyelesaian masalah secara prosedural, sehingga peserta didik tidak dapat meningkatkan kompetensi matematisnya berupa kemampuan pemecahan masalah matematis. Seharusnya guru dapat menyediakan bahan ajar matematika yang sesuai dengan lingkungan peserta didik dan sesuai dengan tuntutan belajar masalah peserta didik di sekolah serta mampu menjawab atau memecahkan masalah/kesulitan belajar peserta didik (Kharisma \& Asman, 2018). Bahan ajar yang sesuai dengan lingkungan peserta didik adalah bahan ajar berbasis kontekstual. Peserta didik dapat terbantu dalam membangun konsep yang dimilikinya melalui materi pada bahan ajar berbasis kontekstual yang memuat kejadian-kejadian nyata dalam kehidupan peserta didik seharihari (Ibrahim, 2012).

Penelitian ini sejalan dengan Sulistyowati \& Putri (2018) bahwa bahan ajar berbasis kontekstual dapat meningkatkan prestasi belajar peserta didik. Penelitian ini juga sejalan dengan Suraji, Maimunah, \& Sehatta (2018) bahwa kemampuan pemecahan masalah peserta didik dapat difasilitasi dengan bahan ajar. Pengembangan bahan ajar berbasis kontekstual dapat meningkatkan kemampuan pemecahan masalah matematis peserta didik karena mampu membuat peserta didik mencapai indikator-indikator yang ada pada kemampuan psemecahan masalah matematis (Rangkuti, Eka, Rangkuti, \& Al-washliyah, 2018) 
DOI: https://doi.org/10.24127/ajpm.v9i4.2976

Pemecahan masalah merupakan hal yang sangat penting dalam pembelajaran matematika dan harus dimiliki oleh setiap peserta didik agar dapat menyelesaikan suatu masalah (Mukasyaf, Fauzi, \& Mukhtar, 2019) Namun kenyataannya kemampuan pemecahan masalah matematis peserta didik masih rendah. Ini sesuai dengan hasil penelitian (Kushendri, \& Zanthy, 2019) mengemukakan bahwa KPMM peserta didik tingkat SMA masih tergolong rendah. Hal ini sejalan dengan hasil studi internasional Programme for International Student Assesment (PISA) tahun 2018 (OECD, 2019) melaporkan bahwa peserta didik Indonesia berada pada posisi peringkat 72 dari 78 negara peserta dengan skor rata-rata kemampuan matematika peserta didik Indonesia yaitu 379 dari skor rata-rata negara 489. Hal ini menunjukkan perlunya meningkatkan kemampuan matematis peserta didik pada KPMM.

Melatih dan mengembangkan KPMM dalam kegiatan belajar mengajar mata pelajaran matematika sangatlah sulit, karena ketersediaan bahan ajar tidak memuat soal KPMM bagi peserta didik dan tidak memuat masalah yang kontekstual. Hasil penelitian Rahayu (2019) menyebutkan bahwa bahan ajar yang digunakan oleh guru adalah bahan ajar sebagai pendamping guru dalam memberikan latihan kepada peserta didik dimana bahan ajar tersebut kurang memfasilitasi guru dalam melaksanakan pembelajaran. Oleh karena itu, perlu dikembangkan bahan ajar matematika yang dapat meningkatkan KPMM peserta didik yang sesuai dengan kehidupan nyata peserta didik (kontekstual).

Berdasarkan uraian yang dipaparkan, maka perlu melakukan penelitian pengembangan bahan ajar berbasis kontekstual untuk meningkatkan KPMM pada materi fungsi kelas X Sekolah Menengah Atas.

\section{METODE PENELITIAN}

Jenis penelitian ini adalah penelitian pengembangan dengan model Borg and Gall. Pengembangan model Borg and Gall yang digunakan merujuk pada teori Syaodih, (2017) yang telah dimodifikasi menjadi 8 tahapan yakni (1) Pengumpulan data dan informasi: peneliti mengumpulan data dan informasi untuk menganalisis kebutuhan peserta didik terhadap bahan ajar yang akan dikembangkan. Hal ini dilakukan dengan analisis kurikulum, analisis kinerja guru dan analisis kerakteristik peserta didik. (2) perencanaan: peneliti merencanakan sistematika penulisan bahan ajar berdasarkan karekateristik peserta didik, merumuskan tujuan dan merencanakan urutan pembelajaran. (3) Desain produk: yaitu dengan menyusun judul bahan ajar, peta konsep, KD/IPK, mendesain materi, soal diskusi dan rangkuman. (4) Validasi desain: Tahap ini dilakukan setelah desain bahan ajar tersusun dan siap untuk divalidasi oleh beberapa ahli untuk melihat sejauh mana bahan ajar yang dibuat mencapai sasaran dan tujuan. Validasi dilakukan oleh ahli materi. Validasi ini meliputi validasi isi/konten, validasi penyajian, validasi kelayakan bahasa dan validasi kelayakan kegrafisan. Instrument yang digunakan adalah lembar validasi oleh ahli materi dan ahli media. (5) Revisi desain produk: tahap ini dilakukan sesuai dengan kritik dan saran yang diberikan oleh validator. (6) Uji coba produk awal yaitu mengujicobakan bahan ajar berbasis kontesktual untuk menilai keterbacaan bahan ajar dengan menggunakan angket respon peserta didik. (7) Revisi produk: tahap ini 
dilakukan berdasarkan hasil dari respon peserta didik setelah uji coba produk awal pada kelompok kecil pada bahan ajar kegiatan belajar 1 sampai 7 yang telah dilakukan. Revisi ini bertujuan untuk penyempurnaan bahan ajar baik secara desain maupun penyampaian materi dalam bahan ajar. Dari saran/komentar peserta didik pada lembar angket respon peserta didik menyarankan bahwa cover dibuat lebih menarik lagi dari tampilan warnanya. (8) Uji coba kelompok besar. Uji coba kelmpok besar dilkukan pada peserta didik kelas X Mia 3 SMA Negeri 1 Rambah Pasir Pengaraian yang terdiri dari 32 peserta didik. Uji coba ini dilakukan untuk mendapatkan data kepraktisan dan keefektifan bahan ajar yang dikembangkan. Data kepraktisan diperoleh dari hasil penilaian yang dilakukan oleh guru dan peserta didik, sedangkan data keefektifan diperole dari hasil tes kemampuan pemecahan masalah matematis peserta didik.

Instrumen pengumpulan data berupa lembar validasi, angket respon peserta didik dan lembar tes KPMM. Lembar validasi terdiri dari lembar vaidasi bahan ajar panduan peserta didik dan panduan guru. Angket respon peserta didik digunakan untuk melihat kepraktisan penggunaan bahan ajar berbasis kontekstual. lembar tes KPMM untuk memperoleh keefektifan bahan ajar berbasis kontekstual. Teknik analisis data yang digunakan untuk memenuhi kualitas bahan ajar berbasis kontekstual panduan peserta didik dan panduan guru yang dikembangkan terutama dari aspek kevalidan adalah data berupa jumlah skor lembar isntrumen dari para ahli yang digunakan. Jumlah skor yang diperoleh dari ahli validasi dipersentasekan dengan perhitungan pada rumus (1)
$N=\frac{\sum \text { skor yang diperoleh }}{\text { skor maksimum }} \times 100 \%$

Sumber: (Riduwan, 2015)

Kemudian dikonversikan menjadi data kualitatif skala lima. Seperti ditunjukkan pada Tabel 1.

Tabel 1. Kategori validitas bahan ajar.

\begin{tabular}{ccc}
\hline No & Interval & $\begin{array}{c}\text { Tingkat } \\
\text { Validitas }\end{array}$ \\
\hline 1 & $80 \%<x \leq 100 \%$ & Sangat Baik \\
2 & $60 \%<x \leq 80 \%$ & Baik \\
3 & $40 \%<x \leq 60 \%$ & Cukup \\
4 & $20 \%<x \leq 40 \%$ & Kurang \\
5 & $0 \%<x \leq 20 \%$ & Tidak Layak \\
\hline
\end{tabular}

Kualitas bahan ajar berbasis kontekstual dikatakan valid jika berada pada kategori minimal baik. Data kepraktisan bahan ajar berbasis kontekstual diperoleh berdasarkan hasil angket respon peserta didik dengan menggunakan skala Likert empat skalan yaitu sangat setuju, setuju, kurang setuju dan tidak setuju.

Skor yang diperoleh dihitung jumlah total skornya, kemudian skor dirubah dalam bentuk persentase menggunakan rumus (2):

$$
p=\frac{f}{N} \times 100 \%
$$

Keterangan:

$p$ adalah nilai akhir

$f$ adalah perolehan skor

$N$ adalah skor maksimum

Persentase skor yang diperoleh kemudian dirata-ratakan, kemudian hasil rata-rata penilaian dikonversikan menjadi data kualitatif skala lima, dengan kriteria praktikalitas pada Tabel 2. Analisis data untuk mengetahui keefektifan dari bahan ajar berbasis kontekstual yang dibuat adalah dengan lembar tes KPMM. Berikut pemberian skor hasil tes KPMM disajikan pada Tabel 3. 
DOI: https://doi.org/10.24127/ajpm.v9i4.2976

Tabel 2. Kriteria praktikalitas bahan ajar

\begin{tabular}{ccc}
\hline No & Interval & Kriteria \\
\hline 1 & $0 \%-20 \%$ & Tidak praktis \\
2 & $21 \%-40 \%$ & Kurang \\
& & praktis \\
3 & $41 \%-60 \%$ & Cukup praktis \\
4 & $61 \%-80 \%$ & Praktis \\
5 & $81 \%-100 \%$ & Sangat praktis \\
Sumber: diadaptasi dari & Akbar (2013)
\end{tabular}

Tabel 3. Pedoman penskoran KPMM

\begin{tabular}{lrl}
\hline $\begin{array}{c}\text { Aspek yang } \\
\text { Dinilai }\end{array}$ & Skor & \multicolumn{2}{c}{ Keterangan } \\
\hline Memahami & 0 & Tidak menyebutkan \\
masalah & apa yang diketahui \\
& dan apa yang \\
& ditanyakan. \\
1 & Menyebutkan apa \\
& yang diketahui \\
& tanpa menyebutkan \\
& apa yang \\
& ditanyakan atau \\
& sebaliknya \\
2 & Menyebutkan apa \\
& yang diketahui dan \\
& apa yang \\
ditanyakan tapi & kurang tepat. \\
& Menyebutkan apa \\
& yang diketahui dan \\
& apa yang \\
& ditanyakan secara \\
& tepat.
\end{tabular}

Membuat

Rencana

Penyelesaian

0 Tidak ada rencana atau membuat rencana yang tidak relevan

1 Membuat rencana yang tidak dapat dilaksanakan, sehingga tidak dapat dilaksanakan

2 Membuat rencana yang benar tetapi salah dalam hasil atau tidak ada

\begin{tabular}{|c|c|c|}
\hline $\begin{array}{c}\text { Aspek yang } \\
\text { Dinilai }\end{array}$ & Skor & Keterangan \\
\hline & 3 & $\begin{array}{l}\text { hasilnya } \\
\text { Membuat rencana } \\
\text { benar tetapi belum } \\
\text { lengkap } \\
\text { Membuat rencana } \\
\text { sesuai dengan } \\
\text { prosedur dan } \\
\text { mengarah pada } \\
\text { solusi yang benar }\end{array}$ \\
\hline $\begin{array}{l}\text { Melaksanakan } \\
\text { Rencana }\end{array}$ & $\begin{array}{l}0 \\
1\end{array}$ & $\begin{array}{l}\text { Tidak melakukan } \\
\text { rencana/perhitungan } \\
\text { Melaksanakan } \\
\text { prosedur yang benar } \\
\text { dan mungkin } \\
\text { menghasilkan } \\
\text { jawaban benar } \\
\text { tetapi salah } \\
\text { perhitungan } \\
\text { Melakukan proses } \\
\text { yang benar dan } \\
\text { mendapatkan hasil } \\
\text { yang benar }\end{array}$ \\
\hline
\end{tabular}

\begin{tabular}{lrl}
$\begin{array}{l}\text { Memeriksa } \\
\text { Kembali }\end{array}$ & 0 & $\begin{array}{l}\text { Tidak ada } \\
\text { pemeriksaan atau } \\
\text { keterangan lain }\end{array}$ \\
& 1 & $\begin{array}{l}\text { Ada pemeriksaan } \\
\text { tetapi tidak tuntas }\end{array}$ \\
2 & $\begin{array}{l}\text { Pemeriksaan } \\
\text { dilakukan untuk } \\
\text { melihat kebenaran } \\
\text { proses }\end{array}$ \\
\hline
\end{tabular}

Sumber: Diadaptasi dari (Amam, 2017)

Analisis data tes KPMM peserta didik dilakukan dengan cara menghitung skor masing-masing peserta didik yang menjawab benar dalam menyelesaikan soal tes KPMM pada materi fungsi, kemudian dikualifikasikan sesuai dengan Tabel 4. 
DOI: https://doi.org/10.24127/ajpm.v9i4.2976

Tabel 4. Kriteria KPMM peserta didik.

\begin{tabular}{cc}
\hline Nilai & Kualifikasi \\
\hline $85,00-100$ & Sangat baik \\
$70,00-84,99$ & Baik \\
$55,00-69,99$ & Cukup \\
$44,00-54,99$ & Kurang \\
$0-39,99$ & Sangat kurang \\
\hline
\end{tabular}

Sumber: Adaptasi dari Mawaddah \& Anisah, (2015)

\section{HASIL DAN PEMBAHASAN}

\section{Desain Produk}

Bahan ajar berbasis kontekstual berisi materi fungsi sesuai dengan kurikulum 2013. Bahan ajar ini dibuat untuk tujuh kali pertemuan dengan pengelompokkan materi sebagai berikut: (1) Relasi dan penyajian relasi. (2) menentukan notasi fungsi, daerah asal, daerah kawan dan range dari suatu fungsi, (3) fungsi linear, (4) fungsi kuadrat dan fungsi rasional, (5) operasi aritmatika pada fungsi, (6) komposisi fungsi, dan (7) invers suatu fungsi.

Bahan ajar matematika didesain dalam bentuk Gambar 1 .

1. Halaman sampul/cover

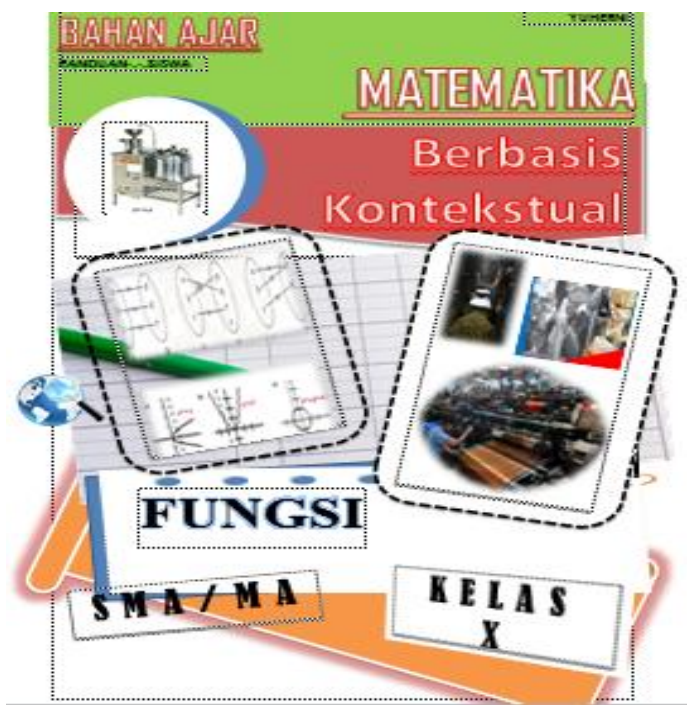

Gambar 1. Sampul (Cover).

2. Kata pengantar. Kata pengantar berisi ucapan terimakasih penulis pada Tuhan YME dan semua pihak, tujuan penulis dalam penggunaan bahan ajar serta harapan yang diinginkan penulis dalam penggunaan bahan ajar tersebut.

3. Petunjuk penggunaan bahan ajar meliputi daftar isi, kompetensi dasar, peta konsep dan tujuan pembelajaran.

4. Kegiatan belajar, bagian ini berisikan uraian materi yang memuat gambar berwarna beserta ilustrasinya dan contoh masalah serta cara penyelesaiannya dan soal diskusi yang akan dikerjakan peserta didik secara berkelompok.

5. Rangkuman. Rangkuman disusun dengan tujuan mengulas materi yang dianggap penting yang telah dipelajari

6. Daftar pustaka. Daftar pustaka disusun untuk memberikan informasi dan arahan bagi pembaca yang ingin meneruskan kajian untuk melakukan pengecekan ulang terhadap bahan ajar

\section{Validasi Desain}

Validitas dilakukan untuk menentukan apakah bahan ajar matematika secara keseluruhan sudah memenuhi kriteria valid. Rata-rata hasil validasi bahan ajar pada aspek isi, aspek penyajian, aspek bahasa dan aspek kekontekstualisasi adalah 81,09 berdasarkan penilaian dari validator. Hasil validasi bahan ajar pada aspek materi dapat dilihat dengan kriteria sangat valid.

Hasil validasi bahan ajar panduan peserta didik ditunjukkan pada Tabel 5. Tabel 5 menunjukkan bahwa hasil validasi bahan ajar matematika panduan peserta didik berbasis kontekstual pada materi fungsi kelas $\mathrm{X}$ dinilia telah valid dengan rata-rata keseluruhan $81,08 \%$ yang berarti masuk dalam kriteria sangat valid. Hasil validasi bahan ajar matematika panduan peserta didik 
berbasis kontekstual untuk tiap aspek media dapat dilihat pada Tabel 6 .

Tabel 5. Hasil validasi bahan ajar panduan peserta didik pada aspek materi.

\begin{tabular}{llcl}
\hline No & $\begin{array}{c}\text { Aspek yang } \\
\text { dinilai }\end{array}$ & $\begin{array}{c}\text { Rata- } \\
\text { rata } \\
(\%)\end{array}$ & Kriteria \\
\hline 1 & Isi & 84,5 & Sangat Valid \\
2 & Penyajian & 83,46 & Sangat Valid \\
3 & Bahasa & 81,41 & Sangat Valid \\
4 & $\begin{array}{l}\text { Kontekstual- } \\
\text { isasi }\end{array}$ & 74,95 & Sangat Valid \\
\multicolumn{2}{l}{ Rata-rata total } & 81,08 & Sangat Valid \\
\hline
\end{tabular}

Tabel 6. Hasil validasi bahan ajar panduan peserta didik pada aspek media

\begin{tabular}{lccl}
\hline No & $\begin{array}{c}\text { Aspek } \\
\text { yang } \\
\text { dinilai }\end{array}$ & $\begin{array}{c}\text { Rata- } \\
\text { rata } \\
(\boldsymbol{\%})\end{array}$ & Kriteria \\
\hline 1 & Ukuran & 88,69 & Sangat Valid \\
2 & Cover & 84,18 & Sangat Valid \\
3 & Desain isi & 83,70 & Sangat Valid \\
Rata-rata total & 85,52 & Sangat Valid \\
\hline
\end{tabular}

Tabel 6 menunjukkan bahwa hasil validasi bahan ajar matematika panduan peserta didik berbasis kontekstual dinilai dari aspek media pada materi fungsi kelas X dinilia telah valid. Secara keseluruhan nilai rata-rata dari tiga orang validator yaitu $85,52 \%$ yang berarti masuk dalam kriteria sangat valid.

Selain validasi bahan ajar panduan peserta didik, validator juga memvalidasi bahan ajar matematika panduan guru. Validasi bahan ajar panduan guru juga dinilai oleh tiga oang validator. Validasi untuk bahan ajar panduan guru pada materi fungsi juga dinilai dari 4 aspek yaitu aspek kelayakan isi, aspek kelayakan penyajian, aspek kelayakan bahasa dan aspek penilaian kontekstual. Hasil validasi aspek materi pada bahan ajar guru dapat dilihat pada Tabel 7 .
Tabel 7. Hasil validasi bahan ajar panduan guru pada aspek materi.

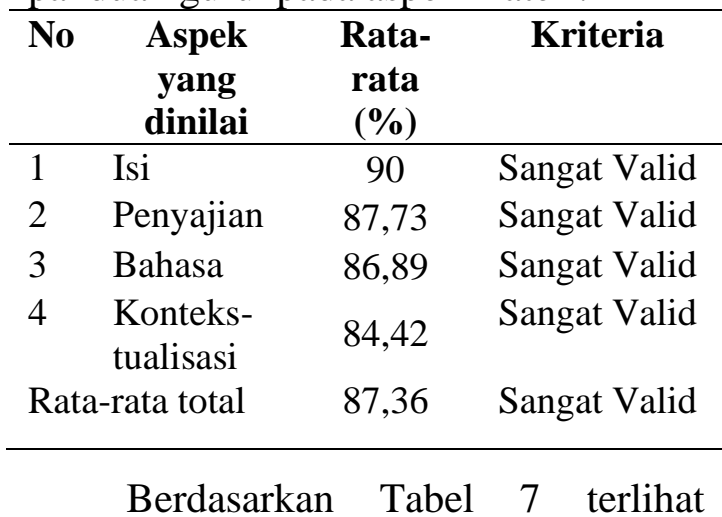

bahwa hasil validasi secara keseluruhan memeproleh nilai rata-rata dari validator yaitu $87,36 \%$ yang berarti masuk dalam kriteria sangat valid dan layak digunakan oleh peserta didik dalam proses pembelajaran. Sedangkan validasi bahan ajar panduan guru pada aspek media ditunjukkan pada Tabel 8 . Berdasarkan Tabel 8 terlihat bahwa hasil validasi dari aspek media untuk bahan ajar panduan guru memperoleh rata-rata persentase secara keseluruhan 90,18\% dengan kriteria sangat valid. hal ini berarti bahan ajar panduan guru layak digunakan.

Tabel 8. Hasil validasi bahan ajar panduan guru pada aspek media.

\begin{tabular}{lccc}
\hline No & $\begin{array}{c}\text { Aspek } \\
\text { yang } \\
\text { dinilai }\end{array}$ & $\begin{array}{c}\text { Rata- } \\
\text { rata } \\
(\boldsymbol{\%})\end{array}$ & Kriteria \\
\hline 1 & Ukuran & 91,67 & Sangat Valid \\
2 & Cover & 87,59 & Sangat Valid \\
3 & Desain isi & 91,30 & Sangat Valid \\
Rata-rata total & 90,18 & Sangat Valid \\
\hline
\end{tabular}

Selain validasi bahan ajar panduan peserta didik dan panduan guru, validator juga memberikan penilaian terhadap soal uji KPMM yang meliputi aspek materi, aspek kontruksi dan aspek bahasa. Rata-rata nilai perolehan validasi soal tes uji KPMM adalah $84,72 \%$ dengan kriteria sangat valid. ini berarti soal tes uji KPMM layak digunakan untuk melihat 
DOI: https://doi.org/10.24127/ajpm.v9i4.2976

kemampuan pemecahan masalah matematis peserta didikpada materi fungsi.

\section{Revisi Desain Produk}

Bahan ajar berbaasis kontekstual yang telah divaldiasi, kemudian dianalisis hasilnya. Selanjtnya peneliti melakukan revisi sesuai dengan saran dari validator yang terdapat pada lembar validasi. Berikut adalah catatan dan saran dari validator dapat dilihat pada Tabel 9.

Tabel 9. Komentar dan saran validator.

\begin{tabular}{clr}
\hline No & Komentar dan Saran Validator \\
\hline 1 & $\begin{array}{l}\text { Perbaiki cover depan karena } \\
\text { terlalu ramai gambarnya }\end{array}$ \\
2 & $\begin{array}{l}\text { Perbaiki penyajian } \\
\text { gambar/masalah lebih }\end{array}$ \\
& $\begin{array}{l}\text { kontekstual lagi dengan daerah } \\
\text { sekolah peserta didik }\end{array}$ \\
3 & $\begin{array}{l}\text { Perbaiki isi bahan ajar yang } \\
\text { terlalu banyak teks, manipulasi }\end{array}$ \\
kalimatnya ke bentuk tabel, \\
diagram, dll \\
Perbaiki kesalahan penulisan dan \\
perjelas gambar-gambar
\end{tabular}

\section{Uji Coba Produk Awal}

Setelah revisi validasi bahan ajar, maka dilakukan uji coba produk kelompok awal penggunaan bahan ajar berbasis kontekstual kepada 9 orang peserta didik. Uji coba ini dilakukan sebelum uji efektivitas produk dengan menggunakan 9 orang peserta didik kelas X Mia 2 SMA Negeri 1 Rambah yang mempunyai kemampuan yang heterogen. Bahan ajar yang digunakan peserta didik yaitu tujuh kegiatan pembelajaran. Setelah peserta didik selesai menggunakan bahan ajar, peneliti memberikan angket respon peserta didik yang harus diisi oleh peserta didik. Tabel 10 adalah hasil dari respon peserta didik uji coba skala kecil pada beberapa aspek tentang penggunaan bahan ajar berbasis kontekstual.

Tabel 10. Hasil uji kelompok coba produk awal tehadap bahan ajar.

\begin{tabular}{lcc}
\hline $\begin{array}{c}\text { Aspek yang } \\
\text { Dinilai }\end{array}$ & Persentase & Kriteria \\
\hline Ketertarikan & $85,56 \%$ & $\begin{array}{l}\text { Sangat } \\
\text { Praktis } \\
\text { Materi }\end{array}$ \\
Bahasa & $82,22 \%$ & $\begin{array}{l}\text { Sangat } \\
\text { Praktis }\end{array}$ \\
Rata-rata & $\mathbf{8 3 , 7 0 \%}$ & $\begin{array}{l}\text { Pangat } \\
\text { Praktis } \\
\text { Sangat } \\
\text { Praktis }\end{array}$ \\
\hline
\end{tabular}

Berdasarkan Tabel 10, rata-rata nilai praktikalitas bahan ajar berbasis kontekstual yang dikembangkan memperoleh nilai $83,70 \%$ dengan kriteria "Sangat Praktis" artinya keterbacaan bahan ajar berbasis kontekstual sangat praktis digunakan. Kepraktisan bahan ajar menunjukkan bahwa bahan ajar berbasis kontekstual mudah dan praktis digunakan oleh peserta, memiliki daya ketertarikan, materi yang mudah dipahami dan penggunaan bahasa yang mudah dimengerti.

\section{Uji Coba Lapangan}

Pada tahap ujicoba lapangan produk diujikan dengan sasaran yang lebih besar yaitu melibatkan 32 orang peserta didik kelas $X$ Mia 3 peserta didik SMA Negeri 1 Rambah. Pada uji coba kelompok besar ini, peneliti bertindak sebagai pencamping dan pembibing, agar mudah memberikan arahan atau bimbingan kepada peserta didik yang mengalami kesulitan dalam belajar menggunakan bahan ajar berbasis kontekstual.

Sebelum memulai pembelajaran menjelaskan kepada peserta didik tentang pembelajaran menggunakan 
bahan ajar berbasis kontekstual ini. Kegiatan pembelajaran dilakukan dengan memberikan bahan ajar dan lembar jawaban diskusi kelompok pada masing-masing kelompok. Peserta didik diminta untuk membaca dan memahami isi bahan ajar dan mengikuti prosedur pemecahan masalah yang ada pada bahan ajar. Jika peserta didik mengalami kesulitan dalam memahami pembelajaran, maka peneliti akan memberikan bantuan ataupun arahan. Setelah peserta didik selesai menggunakan bahan ajar dan menyelesaikan soal diskusi yang ada pada bahan ajar, maka peneliti meminta peserta didik untuk mempresentasikan hasil diskusinya di depan kelas. Kemudian di akhir pembelajaran peneliti memberikan angket respon peserta didik dan meminta peserta didik untuk mengisi angket tersebut sesuai dengan pendapat masing-masing. Tabel 11 menyajikan tentang hasil respon peserta didik pada uji coba lapangan.

Tabel 11. Hasil uji coba lapangan terhadap bahan ajar.

\begin{tabular}{|c|c|c|}
\hline $\begin{array}{c}\text { Aspek yang } \\
\text { Dinilai }\end{array}$ & $\begin{array}{c}\text { Rata- } \\
\text { rata } \\
(\%)\end{array}$ & Kriteria \\
\hline Ketertarikan & 86,92 & $\begin{array}{l}\text { Sangat } \\
\text { Praktis }\end{array}$ \\
\hline Materi & 81,58 & $\begin{array}{l}\text { Sangat } \\
\text { Praktis }\end{array}$ \\
\hline Bahasa & 84,64 & $\begin{array}{l}\text { Sangat } \\
\text { Praktis }\end{array}$ \\
\hline Rata-rata & 84,38 & $\begin{array}{l}\text { Sangat } \\
\text { Praktis }\end{array}$ \\
\hline
\end{tabular}

Berdasarkan Tabel 11 diperoleh data angket respon peserta didik pada uji coba kelompok besar, maka bahan ajar berbasis kontekstual untuk meningkatkan kemampuan pemecahan masalah dapat dikategorikan sangat praktis dengan persentase $84,38 \%$. Hal ini menunjukkan bahwa respos peserta didik terhadap kepraktisan bahan ajar berbasis kontekstual pada materi fungsi kelas $\mathrm{X}$ sangat praktis digunakan peserta didik baik dilihat dari daya tariknya, mudah dipahami materinya dan bahasa nya mudah dimengerti oleh peserta didik.

Secara keseluruhan, bahan ajar dinilai sudah baik dan tidak ada revisi lagi setelah uji coba kelompok besar. Kemudian, pada pertemuan terakhir, peneliti melakukan evaluasi yaitu dengan memberikan soal tes KPMM kepada peserta didik kelas X Mia 3. Tes ini dilakukan untuk mengukur ketercapain tujuan pengembangan bahan ajar berbasis kontekstual yang dikembangkan. Adapun tujuannya adalah untuk meningkatkan kemampuan pemecahan masalah matematis siswa pada materi fungsi. Evaluasi dilakukan dengan uji efektivitas yaitu memberikan soal tes KPMM kepada kelas eksperimen (kelas yang menggunakan bahan ajar berbasis kontekstual) dan kelas control (kelas yang menggunakan buku teks dari Kemendikbud). Tes KPMM diberikan kepada peserta didik setelah pembelajaran dengan menggunakan bahan ajar berbasis kontestual. Hal ini dilakukan untuk melihat kemampuan pemecahan masalah peserta didik yang menggunakan bahan ajar berbasis kontekstual.

Tes KPMM terdiri dari 4 soal cerita/uraian yang mencakup aspek kemampuan pemecahan masalah. Soal cerita digunakan karena soal cerita dapat melihat sejauh mana kemampuan siswa dalam menyelesaikan masalah. Soal tes KPMM sesuai dengan indikator kemampuan pemecahan masalah menurut Polya (Daud \& Suharjana, 2010). Tabel 12 berikut menunjukkan perolehan nilai tes KPMM pesert didik 
DOI: https://doi.org/10.24127/ajpm.v9i4.2976

kelas X Mia 3 per indikator setelah menggunakan bahan ajar berbasis kontekstual.

Tabel 12. KPMM peserta didik untuk setiap indikator.

\begin{tabular}{clcl}
\hline No & $\begin{array}{c}\text { Indikator } \\
\text { Pemecahan } \\
\text { Masalah }\end{array}$ & Persentase & Kriteria \\
\hline 1 & $\begin{array}{l}\text { Memahami } \\
\text { masalah }\end{array}$ & 76,57 & Tinggi \\
2 & $\begin{array}{l}\text { Menyusun } \\
\text { rencana } \\
\text { Melaksanakan } \\
\text { rencana } \\
\text { Mengecek }\end{array}$ & 82,88 & $\begin{array}{l}\text { Sangat } \\
\text { kembali } \\
\text { Rata-rata }\end{array}$ \\
\hline
\end{tabular}

Dari Tabel 12 dapat diketahui bahwa secara keseluruhan kemampuan pemecahan masalah siswa dalam menyelesaikan soal tes KPMM melalui langkah-langkah pemecahan masalah berada pada kriteria sangat tinggi dengan persentase keseluruhan $81,08 \%$. Hal ini berarti dalam proses pembelajaran siswa telah mengikuti langkah-langkah penyelesaian masalah yang ada pada bahan ajar berbasis kontekstual yang dikembangkan. Hal ini berarti persentase peserta didik telah memenuhi kategori sangat tinggi dalam KPMM. Maka, kriteria keefektifan bahan ajar berdasarkan hasil tes uji KPMM telah terpenuhi dengan baik.

Berdasarkan analisis hasil validasi pada penelitian ini bahwa bahan ajar matematika berbasis kontekstual dan Soal Kemampuan Pemecahan Masalah Matematis pada materi fungsi sudah memenuhi kriteria valid, praktis dan efektif, sehingga dinyatakan bahwa bahan ajar tersebut dapat digunakan dalam pembelajaran matematika pada materi fungsi.

Nieveen (Purboningsih, 2015) menyatakan bahwa pengembangan bahan ajar dikatakan memiliki kualitas yang baik apabila bahan ajar tersebut valid, praktis dan efektif dan hasil penelitian Zulyadaini, (2017) menyatakan bahwa bahan ajar berbasis kontekstual telah memnuhi kriteria valid dengan Kategori "Sangat Layak" dan memenuhi kriteria praktis dengan kategori "Sangat Praktis" dan Efektif berdasarkan respon peserta didik. Begitu juga dengan hasil penelitian Rahayu (2019) yang menunjukkan bahwa bahan ajar berbasis kontekstual termasuk pada kategori sangat baik, praktis dan efektif untuk meningkatkan prestasi belajar peserta didik.

Berdasarkan uraian hasil validasi bahan ajar matematika berbasis kontekstual panduan peserta didik dan panduan guru dan hasil tes KPMM pada materi fungsi dapat disimpulkan bahwa pengembangan bahan ajar telah memenuhi kriteria kevalidan, kepraktisan dan keefektifan.

\section{Kualitas Bahan Ajar Berbasis Kontekstual}

Kualitas bahan ajar berbasis kontekstual yang dikembangkan dianalisis berdasarikan validitas, kepraktisan dan efektivitas bahan ajar tersebut (Kristanto, Amin, \& Khabibah, 2016). Berikut hasil analisis dari masingmasing kriterianya:

1. Validitas bahan ajar berbasis kontekstual

Bahan ajar berbasis kontekstual panduan peserta didik yang telah divalidasi oleh validator memperoleh rata-rata persentase $81,51 \%$ untuk aspek materi dan $85,52 \%$ pada aspek media dengan kategori sangat valid. Sedangkan, hasil validasi bahan ajar panduan guru pada aspek materi memperoleh rata-rata persentase $87,36 \%$ dan pada aspek media memperoleh rata-rata persentase 90,18\% dengan kriteria masing-masing 
adalah sangat valid. Berdasarkan hasil validasi tersebut, produk hasil pengembangan bahan ajar berbasis kontekstual panduan peserta didik dan panduan guru untuk meningkatkan KPMM telah memenuhi kriteria valid. suatu bahan dapat digunakan dalam proses pembelajaran jika bahan ajar telah memenuhi kriteria valid.

\section{Kepraktisan bahan ajar berbasis} kontekstual

Kepraktisan bahan ajar penduan peserta didik yang dikembangkan dianalisis berdasarkan angket respon peserta didik. Kepraktisan bahan ajar dilihat dari aspek ketertarikan, aspek materi dan penggunaan bahasa dengan masing-masing persentasenya $86,92 \%$, $81,58 \%$ dan $84,64 \%$. Dengan demikian dapat disimpulkan bahwa bahan ajar yang dikembangkan praktis untuk digunakan peserta didik.

Kepraktisan bahan ajar berbasisi kontekstual menunjukkan bahwa bahan ajar tersebut mudah digunakan oleh peserta didik, memiliki daya tarik dan materi yang mudah dipahami serta menggunakan bahasa yang mudah dimengerti oleh peserta didik. Kemudahan penggunaan tersebut merujuk pada seberapa baik materi dan masalah yang disajikan dalam bahan ajar tersebut. penyajian materi tersebut merupakan elemen penting dalam memfasilitasi pembelajaran peserta didik (Zhao \& Sullivan, 2017).

Daya tarik bahan ajar berbasis kontekstual panduan peserta didik berkaitan dengan hasil belajar peserta didik. Proses pembelajaran menggunakan bahan ajar berbasis kontekstual ini membuat peserta didik sangat tertarik dan termotivasi untuk belajar matematika karena peserta didik mudah memahami materi fungsi yang disajikan berupa stimulus dan ilustrasi gambar yang sesuai dengan materi.
Dengan demikian, daya tarik yang dimiliki oleh bahan ajarl dalam penelitian ini akan memfasilitasi peserta didik untuk mempelajari materi secara mandiri atau kelompok dengan baik.

Selain itu bahan ajar berbasis kontekstual dapat membuat peserta didik lebih aktif dalam belajar dan saling bekerjasama dalam memecahkan masalah yang disajikan. Oleh karena itu, bahan ajar berbasis kontekstual ini sangat baik diguanakan dalam proses pembelajaran guna membantu peserta didik dan guru dalam pembelajaran matematika yang bertujuan untuk meningkatkan kemampuan pemecahan masalah matematis

\section{Efektivitas bahan ajar berbasis kontekstual}

Efektivitas bahan ajar berbasis konteksual yang dikembangkan dianalisis berdasarkan hasil tes KPMM peserta didik pada materi fungsi kelas X. Berdasarkan nilai hasil tes KPMM secara keseluruhan terlihat bahwa ratarata nilai tes KPMM untuk kelas eksperimen lebih tinggi dari rata-rata kelas kontrol yaitu 89,16 untuk kelas eksperimen dan 67,97 untuk kelas kontrol. Hal ini berarti rata-rata peserta didik kelas eksperimen telah memenuhi kategori sangat baik.

Bahan ajar berbasis kontekstual yang dikembangkan dalam penelitian ini memiliki dampak praktis dan teorits. Secara praktis, bahan ajar tersebut dapat digunakan oleh guru untuk memfasilitasi peserta didik jenjang SMA dalam pembelajaran materi fungsi melalui kegiatan-kegiatan pembelajaran yang mendorong untuk aktif, kreatif dan kritis serta saling bekerja sama dalam pemecahan masalah. Selain itu, bahan ajar tersebut dapat digunakan oleh peserta didik untuk belajar secara mandiri karena, seperti bahan ajar matematika pada umumnya, bahan ajar 
tersebut memuat masalah-masalah yang kontekstual yang sesuai dengan karakteristik peserta didik SMA Negeri 1 Rambah Pasir Pengaraian, memuat masalah/soal dan pembahasan masalah serta rangkuman-nya. Proses pengembangan bahan ajar berbasis kontekstual secara teoritisnya yaitu dapat digunakan sebagai salah satu rujukan untuk mengembangkan bahan ajar dengan jenis dan tujuan yang sama.

Bahan ajar berbasis kontekstual yang dikembangkan dalam penelitian ini masih memiliki kelemahan yaitu penggunaan nya hanaya dilakukan pada satu sekolah saja, padahal karakteristik peserta didik pada tiap sekolah berbeda-beda, sehingga penerapan pengem-bangan bahan ajar berbasis kontekstual untuk meningkatkan KPMM pada pokok bahasan fungsi belum tentu sama. Selain itu masih terdapat beberapa contoh masalah yang belum konteks dengan kehidupan peserta didik, sehingga perlu pengembangan lebih lanjut untuk memilih masalah-masalah yang sangat kontekstual dengan kehidupan peserta didik. Hal ini bertujuan untuk lebih meningkatkan KPMM peserta didik tingkat SMA pada materi fungsi.

\section{KESIMPULAN DAN SARAN}

Produk yang telah dihasilkan ada dua yaitu bahan ajar matematika berbasis kontekstual panduan peserta didik dan bahan ajar matematika berbasis kontekstual panduan guru untuk meningkatkan KPMM pada materi fungsi untuk Peserta didik tingkat SMA kelas X. Bahan ajar ini telah mendapatkan nilai dengan kriteria kevaldian, kepraktisan dan keefektifan untuk digunakan oleh peserta didik kelas X SMA pada materi fungsi. Saran untuk penelitian selanjutnya, yaitu bagi peneliti lain agar dapat mengembangkan bahan ajar berbasis kontekstual untuk meningkatkan KPMM pada materi lain yang sesuai dengan karakteristik peserta didik dan kemampuan yang dimiliki oleh peserta didik. Agar bahan ajar tersebut dapat digunakan untuk memfasilitasi kemampuan peserta didik yang berbeda-beda.

\section{DAFTAR PUSTAKA}

Akbar, S. (2013). Instrumen Perangkat Pembelajaran. Bandung: PT. Remaja Rosdakarya.

Amam, A. (2017). Penilaian Kemampuan Pemecahan Masalah Matematis Siswa SMP. TEOREMA, 2(1), 39. https://doi.org/10.25157/.v2i1.765

Astiti, K. A., \& Yusuf, Y. H. M. (2018). Pengaruh Penggunaan Bahan Ajar Berbasis Kontekstual Terhadap Peningkatan Pemahaman Konsep Fisika Siswa Materi Suhu Dan Kalor. Jurnal Fisika: Fisika Sains Dan Aplikasinya, 3(3), 185-192. https://doi.org/10.35508/fisa.v3i3. 625

Daud, A., \& Suharjana, A. (2010). Program bermutu. Daud, A., \& Suharjana, A. (2010). Modul matematika SMP program bermutu (Kajian kritis dalam pembelajaran matematika di SMP). Yogyakarta. PPPPTK Matematik.

Ibrahim, I. (2012). Pembelajaran Matematika dengan ICT Sebagai Sarana Pengembangan Kecerdasan Emosional Siswa Menuju Pembangunan Karakter Bangsa. Jurnal Fourier, 1(2), 47. https://doi.org/10.14421/fourier.20 12.12.47-51

Kharisma, J. Y., \& Asman, A. (2018). 
Berorientasi pada Kemampuan Pemecahan Masalah Matematis dan Prestasi Belajar Matematika The Development of ProblemBased Mathematics Instructional Materials Oriented to Students , Mathematics Problem Solving Skill and Students ', 1(1), 34-47.

Kristanto, Y. D., Amin, S. M., \& Khabibah, S. (2016). The Development of Investigative Learning Materials Using Computer Assisted Instruction in the Topic of Reflection for Grade VII. JRAMathEdu (Journal of Research and Advances in Mathematics Education), 1(2), 172-182.

https://doi.org/10.23917/jramathed u.v1i2.4828

Kurniati, A. (2018). Pengembangan Modul Matematika Berbasis Kontekstual Terintegrasi Ilmu Keislaman. Al-Khwarizmi: Jurnal Pendidikan Matematika Dan Ilmu Pengetahuan Alam, 4(1), 43-58. https://doi.org/10.24256/jpmipa.v $4 \mathrm{i} 1.251$

Kushendri, \& Zanthy, L. S. (2019). Analisis Kemampuan Pemecahan Masalah Matematis Siswa SMA. Journal On Education, 1(03), 94100.

Mawaddah, S., \& Anisah, H. (2015). Kemampuan Pemecahan Masalah Matematis Siswa Pada Pembelajaran Matematika dengan Menggunakag) di SMPn Model Pembelajaran Generatif (Generative Learning) di SMP. EDU-MAT: Jurnal Pendidikan Matematika, 3(2), 166-175. https://doi.org/10.20527/edumat.v $3 \mathrm{i} 2.644$

Mukasyaf, F., Fauzi, K. M. A., \& Mukhtar, M. (2019). Building Learning Trajectory Mathematical
Problem Solving Ability in Circle Tangent Topic by Applying Metacognition Approach. International Education Studies, $12(2)$, 109. https://doi.org/10.5539/ies.v12n2p 109

OECD. (2019). PISA 2018 Results. Combined Executive Summaries. Journal of Chemical Information and Modeling, 53(9), 1689-1699. Retrieved from www.oecd.org/about/publishing/c orrigenda.htm.

Perwitasari, S., Wahjoedi, \& Akbar, S. (2018). Pengembangan Bahan Ajar Tematik Berbasis Kontekstual. Jurnal Pendidikan: Teori, Penelitian, Dan Pengembangan, 3(3), 278-285.

Purboningsih, D. (2015). Pengembangan Perangkat Pembelajaran dengan Pendekatan Guided Discovery pada Materi Barisan dan Deret untuk Siswa SMK Kelas X. Seminar Nasional Matematika Dan Pendidikan Matematika UNY 2015, 467-474.

Purwanto, Y., \& Rizki, S. (2015). Pengembangan Bahan Ajar Berbasis Kontekstual Pada Materi Himpunan Berbantu Video Pembelajaran. AKSIOMA Journal of Mathematics Education, 4(1), 67-77.

https://doi.org/10.24127/ajpm.v4i 1.95

Rahayu, T. P. (2019). Pengembangan Bahan Ajar Matematika Berbasis Kontekstual Di Sekolah Dasar ( The Development of Mathemathics Teaching Materials Based on Contextual at Primary School ), 21-30.

Rangkuti, D., Eka, D., Rangkuti, S., \& Al-washliyah, U. M. N. (2018). Pengembangan Bahan Ajar 
DOI: https://doi.org/10.24127/ajpm.v9i4.2976

Matematika Berbasis Kontekstual Untuk Meningkatkan Kemampuan Komunikasi Matematis Siswa. Prosiding Seminar Nasional Hasil Penelitian, (161-172).

Riduwan. (2015). Skala Pengukuran Variabel-variabel Penelitian. Bandung: Alfabeta.

Sulistyowati, P., \& Putri, N. M. (2018). Pengembangan Bahan Ajar Modul Berbasis Contextual Teaching and Learning (CTL) Kelas IV Tema 3 Subtema 1. Jurnal Pendidikan (Teori Dan Praktik), 3(1), 1. https://doi.org/10.26740/jp.v3n1.p 1-6

Suraji, Maimunah, \&Sehatta Saragih. (2018). Analisis Kemampuan Pemahaman Konsep Matematis dan Kemampuan Pemecahan Masalah Matematis Siswa SMP pada Materi Sistem Persamaan Linear Dua Variabel (SPLDV). Suska Journal of Mathematics Education, 4(1), 9-16. https://doi.org/0.24014/sjme.v3i2. 3897
Syaodih, N. (2017). Methode Penelitian Pendidikan. Bandung: Remaja Rosdakarya.

Zhao, H., \& Sullivan, K. P. H. (2017). Teaching presence in computer conferencing learning environments: Effects on interaction, cognition and learning uptake. British Journal of Educational Technology, 48(2), 538-551.

https://doi.org/10.1111/bjet.12383

Zulyadaini, D. (2017). A Development of Students' Worksheet Based on Contextual Teaching and Learning. IOSR Journal of Mathematics, 13(01), 30-38. https://doi.org/10.9790/57281301033038 